\title{
Carnets
}

Revue électronique d'études françaises de l'APEF

Première Série - 1 Numéro Spécial | 2009

Cultures littéraires : nouvelles performances \& développement

\section{Digital Poetry: a Naissance of a New Genre?}

\section{Giovanna di Rosario}

\section{(2) OpenEdition}

1 Journals

\section{Edição electrónica}

URL: http://journals.openedition.org/carnets/3762

DOI: $10.4000 /$ carnets.3762

ISSN: 1646-7698

Editora

APEF

Edição impressa

Data de publição: 1 Junho 2009

Paginação: 183-205

Refêrencia eletrónica

Giovanna di Rosario, «Digital Poetry: a Naissance of a New Genre? », Carnets [Online], Première Série 1 Numéro Spécial | 2009, posto online no dia 16 junho 2018, consultado o 01 maio 2019. URL : http:// journals.openedition.org/carnets/3762; DOI : 10.4000/carnets.3762

\section{(c) (i) (9)}

Carnets est mis à disposition selon les termes de la licence Creative Commons - Atribution - Pas d'utilisation commerciale 4.0 International. 


\title{
DIGITAL POETRY: A NAISSANCE OF A NEW GENRE?
}

\author{
GIOVANNA DI ROSARIO \\ IN3 Internet Interdisciplinary Institute \\ UOC Universitat Oberta de Catalunya \\ gdi_rosario@uoc.edu
}

\section{Resumo}

Este trabalho terá como tema e como objecto de estudo práticas da poesia digital: ou seja entender esta acção como prática criativa e prática da "leitura". Ler é sempre ler: esta acção consiste sempre em perceber e utilizar os sinais derivados pelo trabalho de um "autor", de qualquer modo, a ordem, o nível de atenção exijido pela leitura de textos eletrônicos, textos ambíguos, instáveis e fluidos diferem. O computador e a Internet oferecem um campo novo ao jogo creativo da escrita: o computador traz ao de cima a natureza reticular da escrita e do espaço entretanto a Web multiplica e dispersa a sua dimensão. Nós tentaremos então identificar os elementos estratégicos que constituem a poetica do texto digital para estabelecer como esta prática creativa emergente complica a noção do sujeito. Considerando a relação entre a poesia (texto verbal) e as imagens (audiovisuais) analisaremos os poemas digitais que exemplificam as estruturas e os estilos deste novo género de "neo vanguardismo".

\begin{abstract}
This paper will have as its main research object the study of digital poetics practices: creative practice and "lecture" practice. Reading is always reading, i.e. this action consists always in perceiving and picking up signs derived by the work of an "author", however the order, the level of attention demanded by the reading of electronic texts, ambiguous, instable, fluid texts, is different. Computer and internet offer a new field to the creative game of writing: computer finds out the reticular nature of writing and the web space multiplies and disperses the dimensions. We will try then to identify the strategic elements which constitute the poetics of digital texts to establish how this emergent creative practice complicates the notion of genre. By considering the relation between poetry (verbal text) and images (audio-visual) we shall be analyzing digital poems which exemplify the structures and styles of this kind of new avant-garde genre.
\end{abstract}

Palavras-chaves: Poesia digital, Prática criativa, Prática da "leitura"

Keyword: Digital poetry, Creative practice, Reading practice 
Normally, when speaking about contemporary literature, no one quotes literature on line, i.e. electronic literature. If contemporary art makes one think about multi-media, contemporary literature evokes generally only the recent production of traditional publishers. Poetry is probably even in a more frustrated condition, since it tends usually to remind of an old and passed genre. However, with communication and information technologies, ICT, both literature and poetry were freed from the paper medium to explore new ways of expressions. During the last years, poetry has been the object of deep reflections and new experimentations.

We traditionally call poetry an artistic experience related to the word both in oral and written form, whose composition unity is the verse line (alexandrine verse, free verse, etc.). The oral medium should be normally richer. The written poetry, in fact, translated into the page only the segmental part of a text, but it is not able to show the over-segmental part as the tone, modulation, etc. However, we can say that this discrepancy has been cancelled: for instance, emphasis, oral procedure concerning duration, has its graphic form highlighted.

\section{E-poetry: What Is This?}

E-poetry - short for electronic ${ }^{1}$ poetry - is an avant-garde movement even if the very first experimentations on computer-created poetry appeared at the end of the ' 50 . The ELO Electronic Literature Organization ${ }^{2}$ defines e-literature (so e-poetry, too) as digital literature refers to « works with important literary aspects that take advantage of the capabilities and contexts provided by the stand-alone or networked computer ». This definition includes both work performed in digital media - i.e. "digital born" and work created on a computer but published in print (as, for example, was Brian Kim Stefans's computer-generated poem "Stops and Rebels"). For J-P Balpe, one of the most famous e-writers, e-poetry (and eliterature) concerns only poetical text (with a poetical value) created by computer programming. The problematic concerning ontology is still opened.

Simplifying, digital poetry does not concern digitalization of printed works, (fig. 1) it relates to digital texts (fig. 2).

A Word made Flesh is seldom

And tremblingly partook

Nor then perhaps reported

But have I not mistook

[...]

\footnotetext{
${ }^{1}$ The terms "electronic" and "digital" will be used as synonymous.

2 http://eliterature.org/
} 
A Word that breathes distinctly

Has not the power to die

Fig. 1 - Emily Dickinson (web page The Complete Poems http://www.emilydickinson.it/j1651-

1700.html)

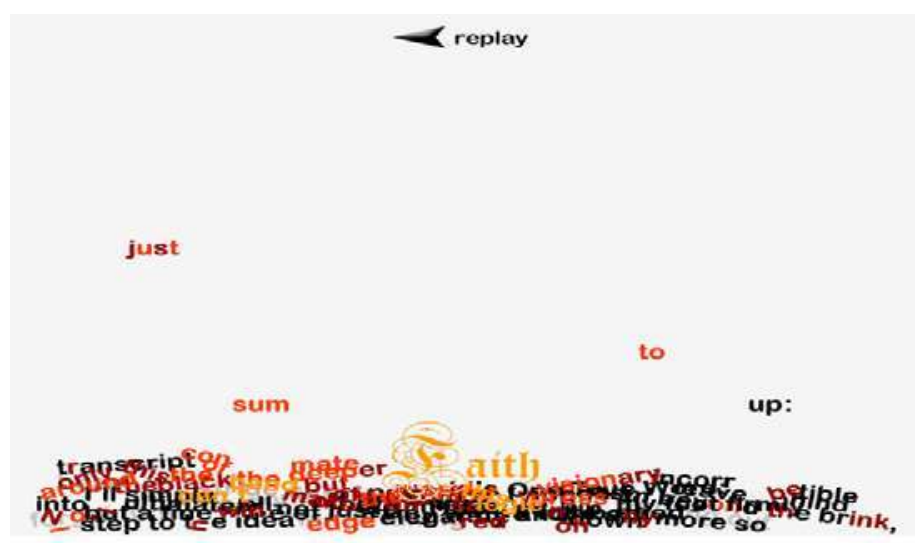

Fig. 2 - Robert Kendall, « Faith »: Electronic Literature Collection, Vol. 1 (web-page: http://collection.eliterature.org/1/works/kendall_faith.html)

These definitions, however, raise questions about which capabilities and contexts of the computer are significant, directing attention not only toward the changing nature of computers but also the new and different ways in which the literary community mobilizes these capabilities. These definitions are also slightly tautological, in that they assume preexisting knowledge of what constitutes an "important literary aspect" or "a "poetical value of the text". Readers come to digital work with expectations formed by print, including extensive and deep tacit knowledge of letter forms, print conventions, and print literary modes. Of necessity, electronic literature must build on these expectations even as it modifies and transforms them.

On the other hand, some critics suggest that many e-poems are simply a reproduction of what avant-gardes, like visual poetry or especially concrete poetry focusing on the materiality of the language, have already experimented, so they wonder what kind of novelty e-poetry is bringing.

\section{Western Visual Poetry Tradition}

Actually, it is true that the fusion of the visual and the literary has always existed. The first known calligrams are the three, 'The hatchet', 'The wings' and 'The egg', created by the Greek poet Simmias of Rhodes at about 300BC. The word calligraphy comes from the Greek 
words kallos, meaning "beauty", and graphos, meaning "writing", so that calligram concerns the visual art that emphasizes the beauty of written sign.

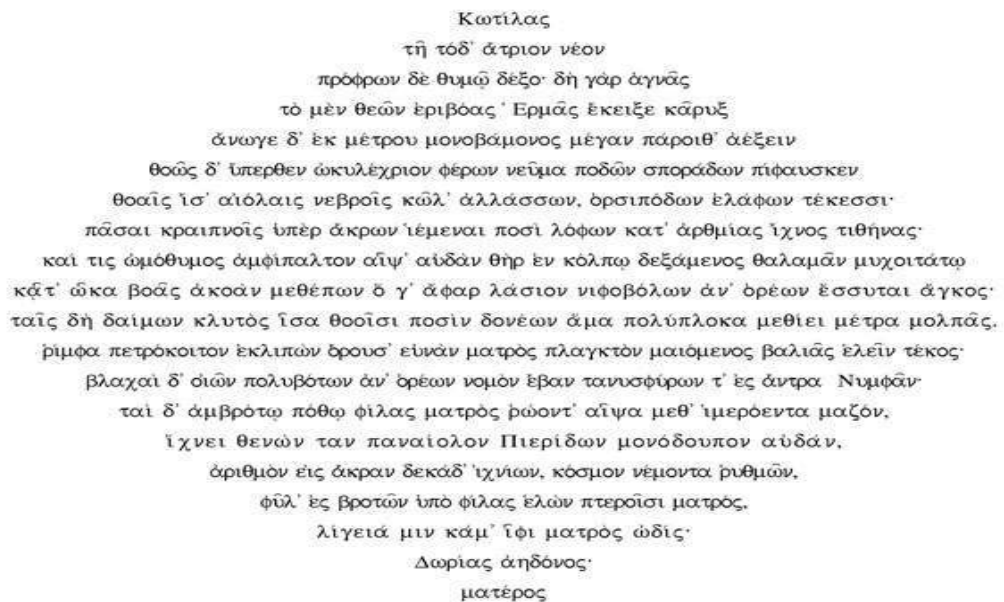

Fig. 3 - Simmias of Rhodes, «The Egg»

Theocrite of Syracuse, then the alexandrine poets, exploited this vein where the drawing and the text are not dissociated but they coincide. It is not just a question of illustrating already written poems, or, conversely, an appendix added to drawings: it is to put together images and writing, or better simulating images by writing.

During the medieval era, manuscripts are illuminated because this new technology allowed decoration. This way, miniature, derived from the Latin minium, red lead, illustrated the codices. There is a physical nexus that connects writing and decoration, and there is a relation of sense and significance between them, too. In the first case, the contribution of the illustrator is found as a part of the written message, while in the second one illustration accompanies the text. Therefore, images were a sort of hermeneutic support for deciphering the written part of the text.

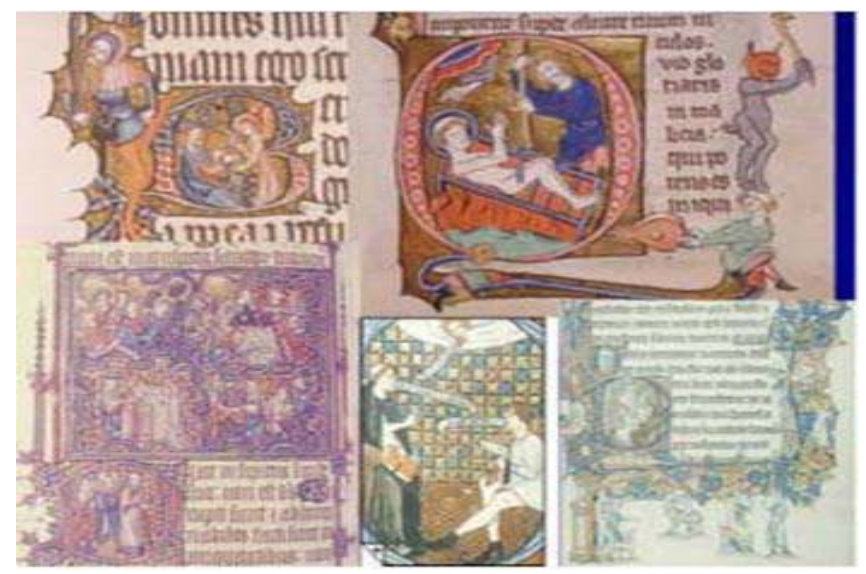

Fig. 4 - Collage of illuminated medieval manuscripts 
During the Renaissance, calligrams have taken a negative connotation. Rabelais used calligrams to create parody.

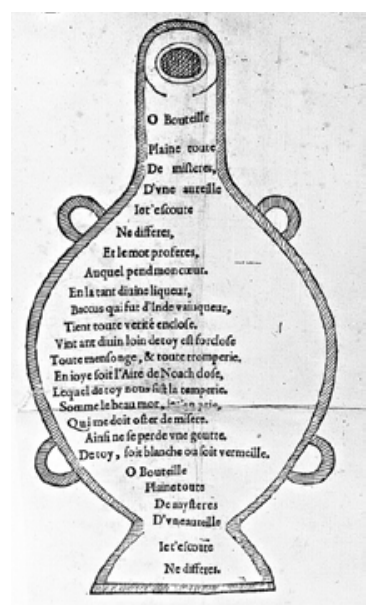

Fig. 5 - François Rabelais, Le cinquiesme et dernier libres des faicts et dicts herö̈ques du bon Pantagruel, 1565

During the $19^{\text {th }}$ century, thanks to Victor Hugo and Charles Nodier, the text form rediscovers its sense in literary activity, though, in these compositions, poetry does not act to represent animals, objects, etc. but it is exploited to give a significant symbolic value to the typography (the use of different types or sizes of characters, the text's position in the page, etc.). In 1829, Hugo publishes in Les Orientales an astonishing text of one hundred twenty rhopalic ${ }^{3}$ verses, entitled "les Djinns".

This connection between visual and writing (a normal aspect in oriental tradition) has carried on along many centuries in western culture, too, even if it is true that with the Gutenberg's era, quoting McLuhan, things changed just because of the new medium. From one side, after the invention of press editions, western poetry has undergone paging rules; on the other, anyway, written poetry has always researched for other/different prosodic elements by using for example colours or new composition form on the page space.

It is Stephan Mallarmé, with his famous Un coup de dés jamais n'abolira le hasard published in 1897 , who traces a difference in poetic experimentations. The text becomes immediately an image. As for the visual dimension, the text follows a new "syntax", using, for instance, capital or tiny letters. Silence is introduced in the reading path by means of the space.

From Mallarmé's Coup de dès, Apollinaire's Calligrammes to the Visual Poetry $\left(20^{\text {th }}\right.$ century), they have been refusing regularity imposed by typography to take advantage of

\footnotetext{
${ }^{3}$ We call "rophalic vers" a verse line in which each successive word has more syllables than the one preceding it. Marie Bélisle's Figure, which will be proposed in the section "Digital Poetry: Close Readings" represents an electronic version of this king of experimental writing.
} 
verse lines, signs, blanks and, sometimes, also of typographic characters' expressivity. Futurists for example, try to practice a kind of poetics that is utterly a poetics of the present. Its achievements will be asyntacticism, the struggle against syntax as a constraining force, simultaneity, the typographical revolution, words in freedom, le tavole parolibere. Futurism promotes the use of the infinitive verb, onomatopoeia and mathematical symbols as a typographical revolution: "on the same page we will use three or four colours of ink, or even twenty different typefaces if necessary". Finally, they will make a free use of expressive orthography: the deformation of words.

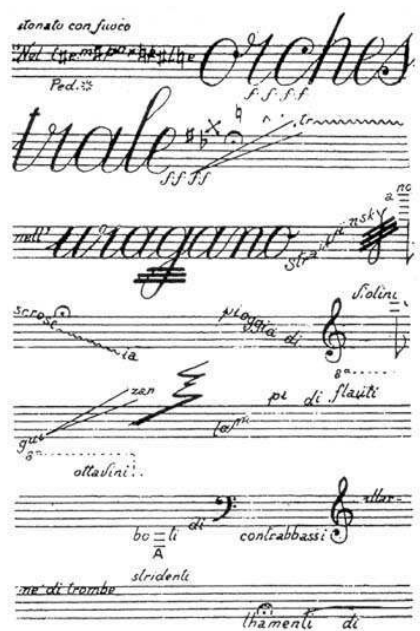

Fig. 6 - F. Cangiaullo, « Poesia pentagramada »

The Cubo-Futurist suggests finding significance in the forms of letters, in the arrangement of text on the page, in the details of typography. The poet should arrange words in the poems like the sculptor arranges colours and lines on the canvas.

As far as Apollinaire and his Calligrammes, he defines his position within and with respect to Futurism. In it he reveals himself as a poet of order and also as a poet of $a(n)$ [r]evolution. On the one hand we find calligrams such as "Il pleut" (1916), which fits perfectly into the ancient tradition of technopaegnia and of the carmina figurate (Fig. 7). 


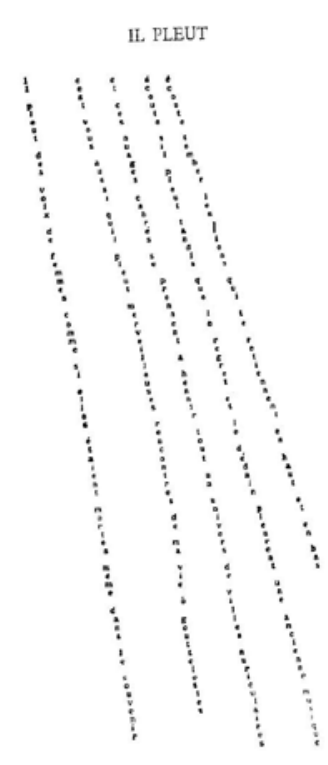

Fig. 7 - G. Apollinaire, « II pleut »

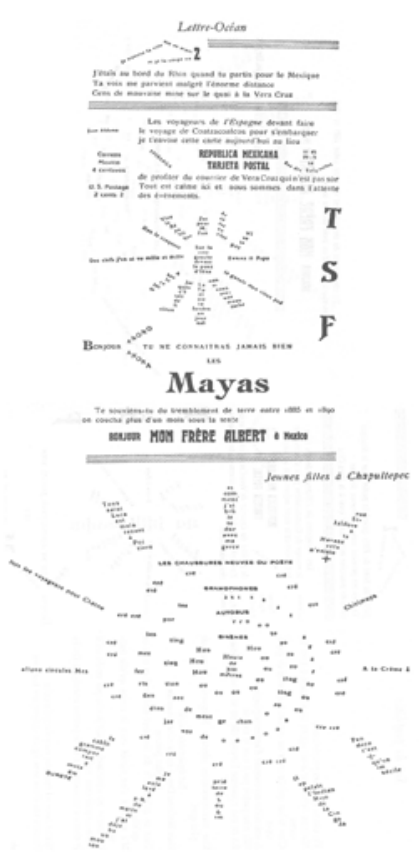

Fig. 8 - G. Apollinaire, « Lettre-Océan »

It has linear verses which are arranged from top to bottom on lines that are slightly slanting in order to contribute to the effect of rain. Here the iconism is used to reinforce the sense of the text. Besides this, it functions as an amusement as well. At the same time we find the "Lettre-Océan" (1914), which is a good example of the management of space on the page (Fig. 8).

The Dada movement tries to express the negation of all standard aesthetic. Dadaists use novel materials and find humorous ways of expression, by using different elements to create art. Tzara, for instance, would begin a poem by cutting words out of some 'old' poem (by Shakespeare, for example), shaking the words up in a hat, and reading them aloud as pulling the bits of paper out of the hat and thereby creating a 'new' poem.

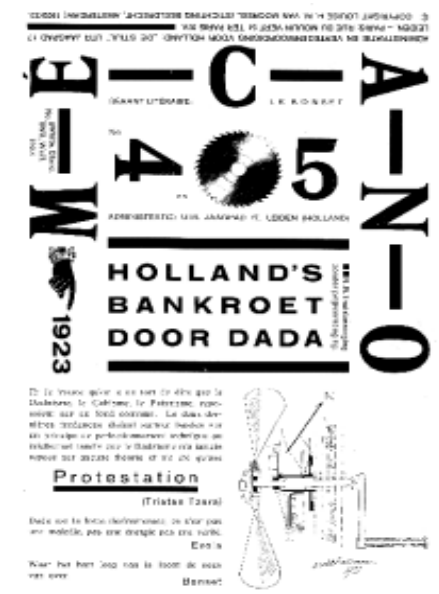

Fig. 9 - Front page of Mecano No. 45, Amsterdam (1923) 
Surrealists use automatic writing to create poetry. Surrealist poetry is exempt from aesthetic judgment. It needs another kind of aesthetic and unconsciously it proposes it. "Turns without reflections to the curves without smiles of shadows with moustaches, registers the murmurs of speed, the miniscule terror, searches under some cold cinders for the smallest birds, those which never close their wings, resist the wind" (Eluard, 2001).

The Lettrist poet works in a variety of forms including sound as well as graphic arts involving letters. Isou (1949) noted that Dada had chiseled art down to the word, while Lettrism was intended to refine it to the letter. "Je préfère mon nouveau dégoût à l'ancien goût dégoûtant" ('d rather have my new distaste than the old distasteful taste). The Lettrist movement has influenced other movementsand continues today, mostly in the form of hypergraphical works and paintings.

Fluxus - a name taken from a Latin word meaning "to flow" - is an international network of artists, composers and designers noted for blending different artistic media and disciplines. They have been active in visual art and music as well as literature, urban planning, architecture, and design. Fluxus is often described as intermedia, a term coined by Fluxus artist Dick Higgins in a famous 1966 essay, Statement on Intermedia. For example, poetry and visual art intersect in visual poetry, and concept, text, and performance intersect in Fluxus Event Scores. Fluxus encourages doing oneself aesthetics, and valued simplicity over complexity.

Like Dada before it, Fluxus includes a strong current of anti-commercialism and an anti-art sensibility, disparaging the conventional market-driven art world in favour of an artistcentered creative practice. Fluxus artists prefer to work with whatever materials were at hand, and either created their own work or collaborated in the creation process with their colleagues. There are some kinds of poetry which traversed last century (but which are still very dynamic) and whose many features are found in electronic poetry: concrete and visual poetry, sound poetry, etc.

Visual and concrete poetry are those which implement "visual meaning of varied nature, plastics or iconic". One will have recognized of course the "calligrammes", which have here the appearance of pioneers for a kind which has largely developed, as we said, beyond Apollinaire and Marinetti (Futurism), and in a tradition which, however, exists since the Ancient Greece. In the Sixties, the image appeared in the poem: photographs, advertising image, icon... and brings there the unverifiable character of its polysemia. It is the starting point of a "pop poetic culture" linked to Andy Warhol. It is during the Eighties, however, that the first digital and electronic experiments are born, as an inheritance of visual and concrete research. 
Sound poetry enjoys a great vitality and an astonishing diversity. Its history goes up with the beginning of the century, even if it truly starts in the Fifties. The more astonishing productions are those which, at the end of the century, exploit the last technologies of sound and communication. It covers the poetic production "bringing into playing the voice and resorting to electroacoustic tools" (microphones, improvisations around the tape recorder, computer...). It integrates a gestural dimension which sometimes connects it with the "performances" developed in the Sixties. Its new devices: the disc, the magnetic tape, the audio cassette, then the video or the CD-ROM.

\section{Digital Poetry: Brief History}

According to Decio Pignattari (1977) concrete poetry, which communicates its own structure "structure content ", announces the arrival of digital poetry. Computer created poetry was born in 1959 at Stuttgart, Federal Republic of Germany, when the German linguistic Max Bense, with the aid of an engineer, Theo Lutz ${ }^{4}$, succeeded to produce the first electronic free verses, using a machinery that was still called "calculator" and not computer. Thanks to the evolution in technology, in the following years other electronic poetry experiment started in Canada and in France where, always in 1959, a French engineer, François Le Lionnais, apparently convinced Raymond Queneau to found the "Séminaire de Littérature Expérimentale", that in 1960 would be changed in the famous Oulipo, "Ouvroir de Littérature Potentielle». As far as the Italian experience is concerned, we shall remember the poem Tape Mark by Nanni Balestrini, made in 1961 with an IBM calculating machine. In 1985, in occasion of an international exhibit held in Paris at the Centre Georges Pompidou, titled "Les Immatériaux", the Alamo group introduced its first poems "generated" by computer, which sanctioned the birth of a new form of visual poetry "animated" by this new medium.

To this technological revolution we should add another important step which took place in 1993, when the technology that has made the net popular was invented. From that date that a proliferation of web-sites of "cyber-poetry" began and, consequently, a new generation of digital authors was born. The advent of the net marks a breaking point with the past and opens up unexpected possibilities to literary creation as well: besides providing new chances to the literary (and poetic) productions, the WWW also allows you to become your own publisher. From then on, we have been witnessing an incessant multiplication of poetic creations published on the net.

\footnotetext{
${ }^{4}$ Almost concurrently in the United States, Brion Gysin was able to do the same thing.
} 
If it is true that every medium develops its own structure, it is also true, from a narratological point of view, that the same medium could make different products (for instance, the book and the newspaper). Digital poetry could be re-defined thanks to the famous equation of McLuhan (1962): not being able to compromise the language anymore, poetry will have to compromise the medium. Electronic writing allows many creative possibilities because it makes visible all the different elements which make the interpretative course of a sign, by arranging in the same visual space verbal signs and audio-visual images. The writing space, i.e. the medium, is made immaterial by these "new" technologies, but the sacrality of the poetic speech is based on the materiality (Greimas, 1972). In this context then, what does become the poetic speech in digital poetry? Could the poetic speech, become, perhaps, fluctuant? That would seem to be true for poems created by a collective of artists, where due to the Internet technology, a virtual community works on the same text, which finally, one would seem to be able to define really open.

By intensifying the dislocation of the structures of the communicative language (Kristeva, 1974), digital technologies seem to increase the poetic variation. The computer and the Internet brought a new spatiality and a new temporality to the text (and also in the poetic text).

According to Katherine Hayles (2007: 5), anyway, "to see electronic literature only true the lens of print is, in a significant sense, not to see it at all". As she states, the multimodality of digital art works challenges writers, users, and critics to bring together diverse expertise and interpretive traditions to understand fully the aesthetic strategies and possibilities of electronic literature.

Electronic literature tests the boundaries of the literary and challenges us to re-think our assumptions of what literature can do and be. Moreover, there are different kinds of epoetry. For instance:

- Dynamic electronic poetry/or flash poetry: the strongly aspect is exactly word and images dynamism. Moreover the dynamism is necessary for the meaning's construction.

- Visual e-poetry: images interact and/or help to decipher the text;

- Digital poetry with a passive interaction: the readers has to click on existed link to "advance" (not only in a linear sense) in the lecture;

- Digital poetry with an active interaction: the reader participates at the creation of the text;

- Generative e-poetry; text generator;

- Collaborative e-poetry; 
- ASCIl poems focusing on the code ${ }^{5}$.

\section{Digital Poetry: Close Readings}

Marie Bélisle's Caractères, work number 1, is composed by two texts as the colours of the letters and the word-buttons on the picture suggest. The page opens with a picture, suddenly a text appears and at once slides down, stopping itself down the picture: the image (the picture) becomes a simulacrum of the writing.
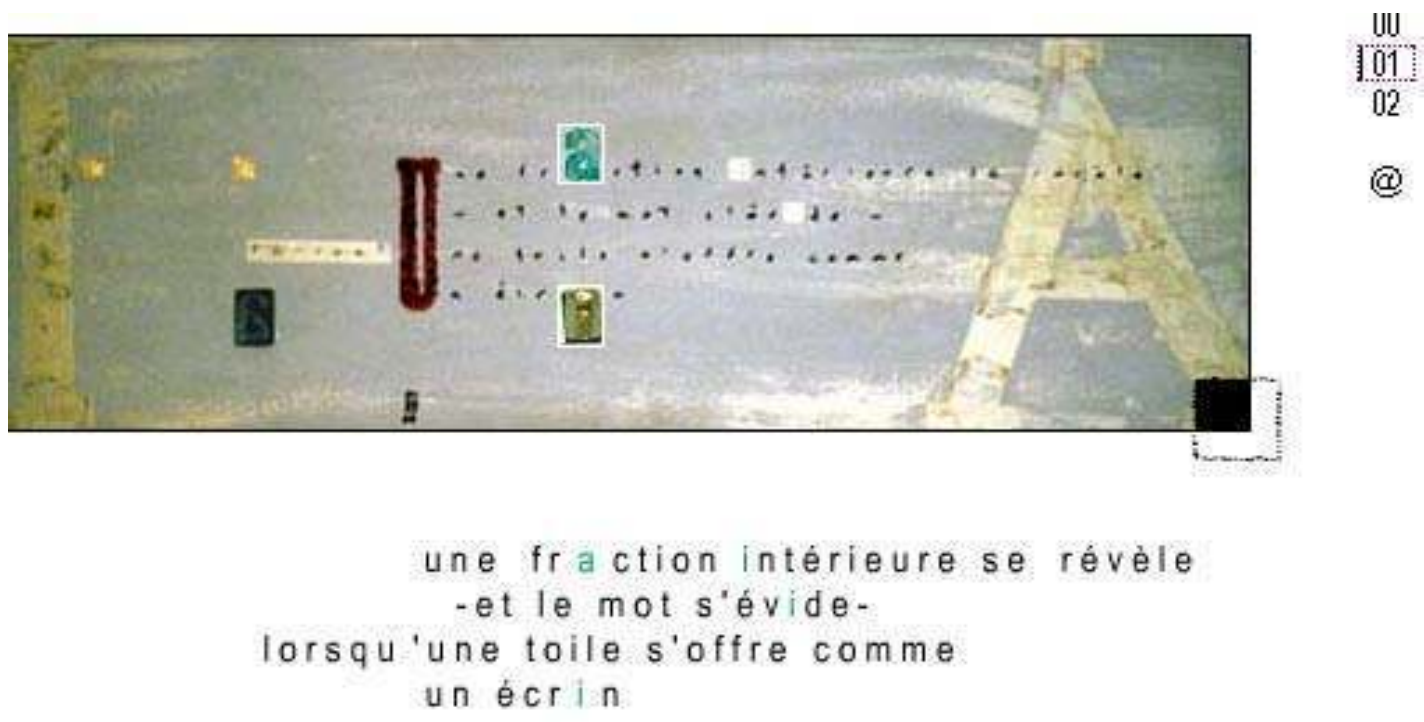

Fig. 10 - Marie Bélisle, Caractères

Two letters are emphasized in the text: a light blue /A/, and a light brown ///. By grazing with the cursor on the $/ \mathrm{A} /$, both in the text and in the picture, the $/ \mathrm{I} /$ will appear, creating new form of words: so from the /A/ of "fraction" we can pass to the /I/ of "friction". The structure, itself, reminds of mathematical fraction. The third line verse "lorsqu'une toile s'offre comme", the only one that in not composed of mutable letters, seems to represent the division between and inside the texts. When the reader opens the page, he/she finds a graphic text moving from a picture, but two vowels remain identifiable in it: an /A/ and an /I/. These two vowels, actually, become the buttons to read two of several combinations of texts. The first one proposes to start with a word containing the vowel /A/ that can be transformed in ///: "fraction" to "friction", the other words containing the vowels /A/I/ are: "intérieur" which becomes "antérieur", the verb "s'évide" becomes "s'évade", (from digging to escaping, from soil to sky) and, finally from an "écrin" we pass to an "écran". So, the single elements can be changed, transforming the text into another and into another... This changing of letters is a

\footnotetext{
${ }^{5}$ Due to the particularity of this kind of creations ASCII poems will not be part of this work.
} 
linguistics commutation, used to identify the significant of a word and then to understand its sense. It is through its form, its substance in Hjelmslev terms, that the poetry will rich its expression. Finally, this text reminds also of a mathematical equation: / $\mathrm{A} /$ is to $/ \mathrm{I} / \mathrm{as} / \mathrm{I} /$ is to $/ \mathrm{A} /$, but the final result is different./ $\mathrm{A} /$ and $/ \mathrm{I} /$ introduce a difference into the repetition: fraction/friction/écrin/écran,... The paradox of the repetition - according to Deleuze (1968: 7) it is that we can speak about the repetition only thanks to the difference and to the change which it introduces. This text is a material work that assembles and forms. Its roots are deep, they are under the text, it is the text itself that invites the reader to "évider" (to dig) in order to find a new shape under the apparent one, in order to find an /A/ instead of an $/ \mathrm{I} /$, passing from an "écran" to an "écrin" (case/casket). Although closed in the casket's screen (écrin /écran), the letters rubbing and splitting (frioctionner/fractionner) to let the word dis/appear.

Another interesting work by Marie Bélisle is Figures. There are four figures:
1. «Figures Variables »
2. «Figures Parallèles »
3. «Figures Constantes »
4. «Figures Tangentes »

The author explains her texts:

Les textes de FIGURES sont construits comme une illustration littéraire du Nombre d'Or et de la suite de Fibonacci. En tant que constante mathématique et esthétique, le Nombre d'Or constitue une "matrice » formelle qui permet de déterminer le nombre de mots et de lignes des textes ainsi que la façon dont ils s'imbriquent l'un dans l'autre. Les textes de FIGURES sont donc des Rectangles d'Or où les mots servent d'unité de mesure horizontale et les lignes d'unité de mesure verticale (Bélisle, 1999).

Figures are built like a literary illustration of the Golden Ratio following Fibonacci's ideas. As an aesthetic and constant mathematics, the Golden Ratio (or Golden Section) constitutes a formal "matrix" which makes possible to determine the number of words and lines in texts as well as the way in which they imbricate one another. Figures are thus Gold Rectangles where the words are used as horizontal measuring unit and the lines as vertical measuring unit. Leonardo Fibonacci is an Italian mathematics of the Middle Ages (11751240 ) and he is recognized the inventor of a succession of numbers founding a link connected with the Golden Section. Each number represents the sum of the two numbers that precede it: $0,1,1,2,3,5,8,13,21,34,55,89,144 \ldots$ The more one advances in the 
series, the more the relationship between two consecutive numbers approaches at Phi, $(1,618): 8 \div 5=1,655 \div 34=1,617144 \div 89=1,6179$

The Greek letter Phi indicates a constant mathematics called Golden Section, its value is of 1,618 . Thus, when the relationship between the height and the width of a rectangle corresponds to Phi, one speaks about a Gold Rectangle: it is the case, for example, of a rectangle of $144 \mathrm{~mm} \times 89 \mathrm{~mm}$.. Largely used in art and in architecture, the Golden Section represents an ideal of balance and elegance of the proportions. It allows, by drawing up a constant relationship, to generate forms harmoniously linking one another thanks to their isomorphism.

Figures as you can see are "text-spirals". The characteristic of these texts, therefore, is that by passing with the cursor on the given segments the text advances or moves back in a symmetrical way, for example in "Figures Variables" from an opening line verse (Figures/variables):

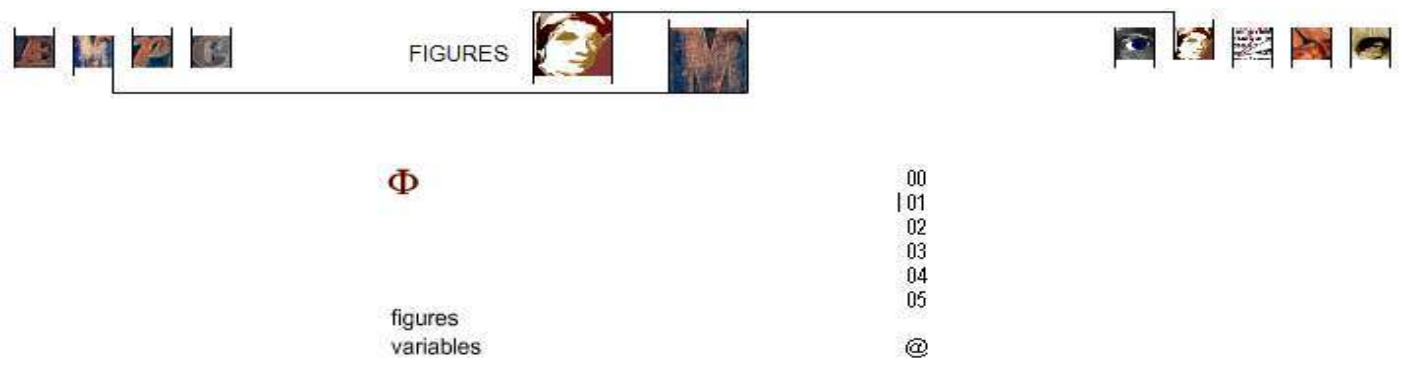

Fig. 11 - Marie Bélisle, Figures (first images)

the reader can reach in only three clicks the complete poem, which will form a rectangle ${ }^{6}$ :
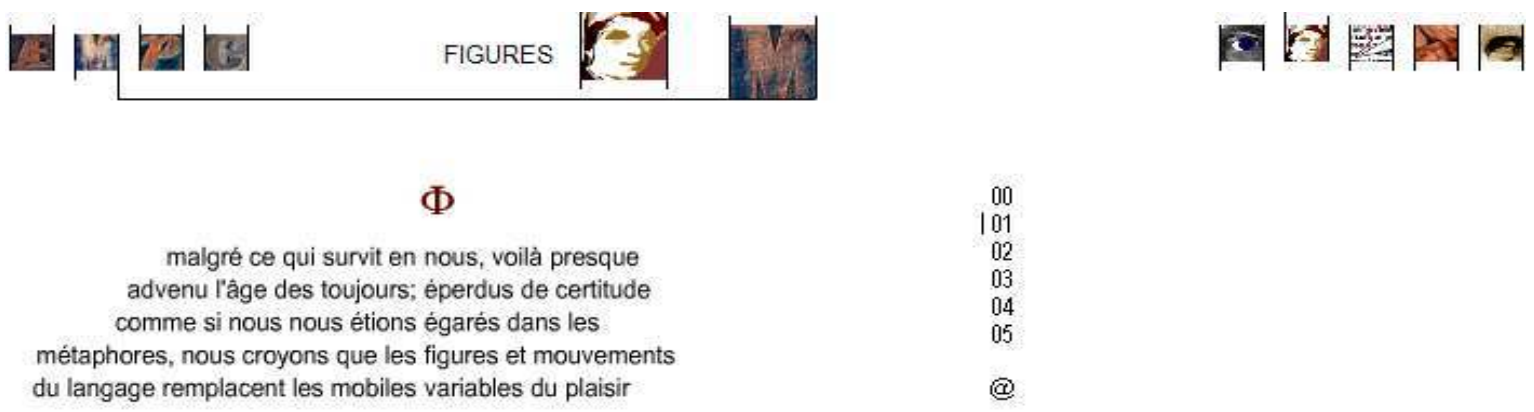

Fig.12 - Marie Bélisle, Figures (last image)

\footnotetext{
${ }^{6}$ «malgré ce qui survit en nous, voilà presque/advenu l'âge de toujours, éperdu de certitude/comme si nous nous étions égarés dans les/métaphores nous croyons que les figures et mouvements/du langage remplacent les mobiles variables du plaisir ».
} 
The words form and deform the sense of the text by moving in the space, doubling the number of the line verses and their meanings, creating figures and movements, metaphors ${ }^{7}$, i.e. substituting a part to another, a sense to another one.

Faith by Robert Kendall can be a perfect example of how words in electronic writing can easily assume a visual value, it can be considered as a concrete poem; nevertheless, this text shows as the dynamism and not only the materiality of the language suggests a second meaning.

I propose to use the semiotic word entax to define this sort of "typographical syntax". We can trace a semiotic difference between syntax and entax. Briefly, if syntax covers the assembly operations of both figures and signs along the external space of a sign system, entax indicates the system of the operations assembling the letters inside the figures. The syntax regulates the grammatical relationships among the linguistics signs; the entax regards the relationship of mutual disposition that is created among the characters in an inscription space.

So the entax comprises all arrangements and combination of typographic elements in the space of a page. According to Wedhe (2000: 119-126) texts usually adhere to specific configuration of typographic elements which serve to identify single text as belonging to a specific text or genre. There is also a pragmatic level of typography and it is embodied in the use of certain type and text-graphic elements for particular envisaged effects.

In attempt to specify the entax we suggest to classify into three domains:

- Micro-entax (morphology) which refers to fonts, letters and to configuration of typographic signs in lines and text blocks, which deals with morpheme: words' forms and colors changing in "Faith";

- Meso-entax (semantic) which relates to the graphic structure of the all document, which refers to the lexeme.

- Macro-entax (pragmatic) which relates to the graphic and visual structure of the all document, which refers to the sentence in its context: "leap" in the poem "Faith" (it recreates the idea of the movement, like the other verbs of movement, but, moreover it suggests that it is necessary "to jump now" to advance in the reading).

Faith is made of a sequence where some pauses are introduced. The sequence, therefore, is divided into five other subsequences; inside these subsequences the process

\footnotetext{
${ }^{7}$ Metaphor is a rhetoric figure: a part can substitute the other because they are linked by a relationship of resemblance.
} 
advances automatically. Between a subsequence and the other, instead, there is a link, which permits the reader to keep on reading the other subsequence. The subsequences, moreover, are made of segments of text that appeared and disappeared according to different time and movements. Every subsequence differs from the others for the way in which the text in the window appears (and inside of each subsequence, some segments differ from the others for the various type of movement that they complete). The first subsequence, for instance, contains the word "Faith", which is also the title, written in orange gothic types and nothing else.

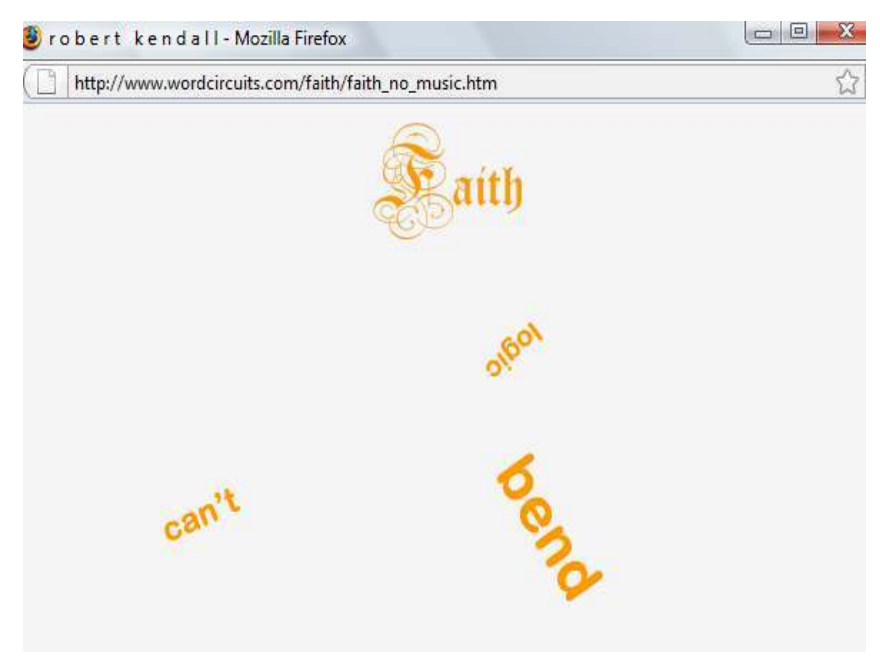

Fig. 13 - Robert Kendall, Faith

Then it begins to fall from the high, the word "logic", which hits and bounces "Faith", afterwards "logic" dissolve itself, accompanied by a metallic sound which increases the frequency with the number of times that the word falls. As far as dimension, "logic" is smaller than "Faith", but both "Faith" and "logic" maintain constant dimensions during the entire sequence. On the contrary, the others words "can' t", "bend", "this", appear with greater dimensions and, by rotating, they diminish progressively until they placed in the right point of the page. The first sub-poetry is finally composed: "Faith. Logic can't bend this. I know...". During the second subsequence new words appear that join the previous ones, modifying and developing the meaning of the text. In this subsequence the words slide horizontally until stopping themselves in a point of the window, their dimensions remain always the same. The colours differ between a subsequence and the other, so that the segments of text that appear in each subsequence are distinguished from those of the previous and the successive ones. As far as the colours in the first subsequence all the words are orange, in second all red, a complementary colour of the orange one. The colours of the words in the successive subsequences are brown and black. So colours are every time more intense, they 
communicate, at the same time, continuity regarding the previous subsequence and growing of the emotions until arriving to black, the last one of colour scale.

During the development of every subsequence, associations among the segments, the movement are created: for example, in the third subsequence, the syntagms "red", "winking" and "neon" flash in the high part of the window just like a neon-light. The visual part, therefore, underlines the metaphor of the text (red, winking neon) emphasizing it, in order to indicate the logic inability to succeed in understanding all phenomena. In the fourth subsequence we have another example: the segments "off the rocker (yippee!)" after being appeared horizontally it slides, simulating a fall. Once again, therefore, the literal meaning of words is represented graphically and is emphasized by the musical foundation (moreover "off the rocker (yippee!)" reminds of the slang expression "off one' s rocker"). All the verbs that indicate movement, after being appeared, doubled themselves in two identical segments, then they assume a less defined colour, but one is raised and it slides away horizontally, while the other remains like pale simulacrum in the same position. Finally, from the left inferior corner appears a syntagm "Leap" (black colour), which, as it has happened to all verbs that indicate movement, doubles itself in two segments. One of these segments occupies the all page.

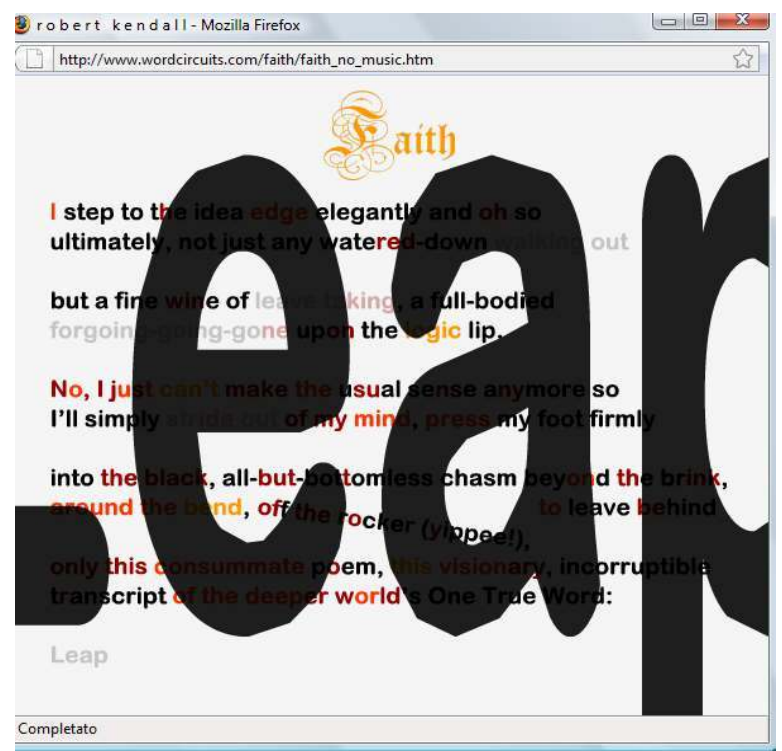

Fig. 14 - Robert Kendall, Faith

It is a visual invitation to the reader to "leap now". In this case we ca speak about a pragmatic level of typography. In this macro-entax example the verb "leap" recreates the idea of the movement, like the other verbs of movement, but, moreover it suggests that it is necessary "to jump now" to advance in the reading. This visual figure of extension, quoting Alexandra Saemmer (2007: 107), creates by the entaxe, is the startup of a narrative process. 
In the last subsequence the reader can finally understand the substantial ambiguity of the poetry: the graphical animation means exactly the contrary of what the text asserts. The text says: "just to sum up: Faith", while the graphical animation, that we can define an iconic one, suggests another meaning: i.e. that everything ends, and faith, too.

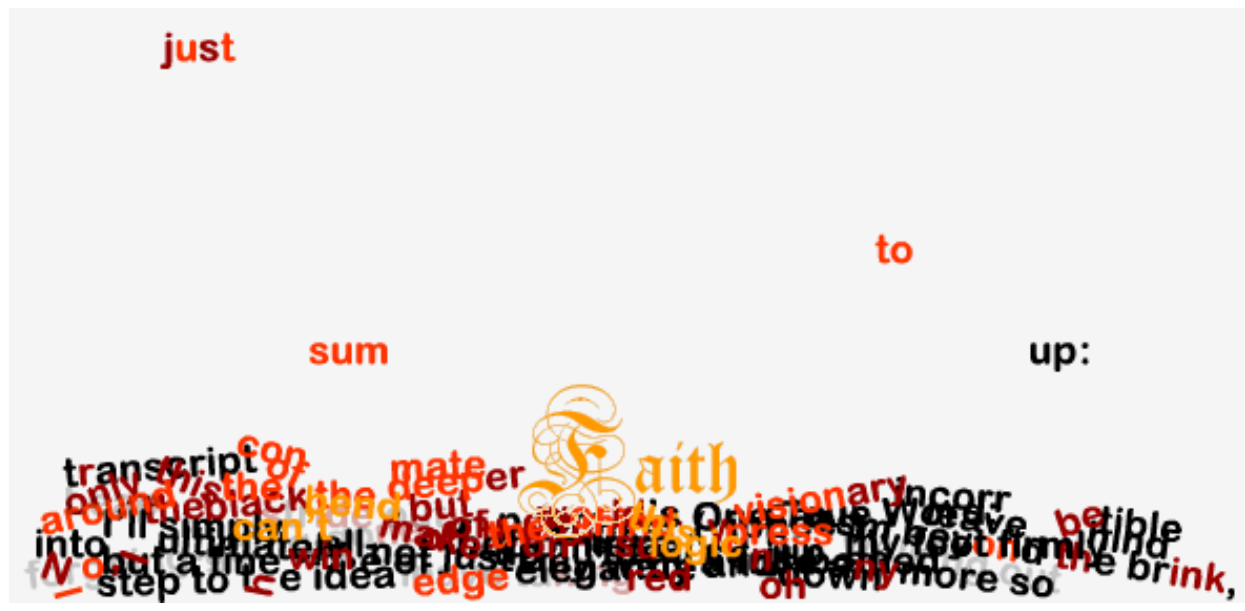

Fig. 15 - Robert Kendall, Faith

Still Standing by Bruno Nadeau is:

an interactive installation that invites participants to stay motionless and contemplate its poetic content, a poem titled seeking sedation. Nowadays, designs are created to be decrypted and enjoyed at a glance, requiring no attention span. The piece evolved as a response to the "collapse of the interval". A phenomenon of fast pace culture that rarely allows us a moment to stop and observe. A habit that weakens the fragile approach towards design with dynamic typography. The installation consists of an amalgam of characters projected on the wall as if they were resting on the floor. When a participant walks in front of the projection, the first reaction of the text is to act as if it was being kicked, pushed by the person's feet. When the participant stops for a short moment, the text is attracted towards his position and moves up, like water soaking his body. The participant can then enjoy a motionless moment and contemplate the textual content that becomes more and more legible. When the user is done and decides to start moving again, the text falls back to the floor and waits for a new interaction (Nadeau, 2003).

Enjoying Still Standings means re-creating physically the text body. The amalgam of characters has to take its material form. When finally it is in front of its reader, this one can start to read it and if he tries to do it with high voice, at the first time, because of the text form, the sound reproduced remind of a robotic sound, allowing the material sound of letters emerging. 


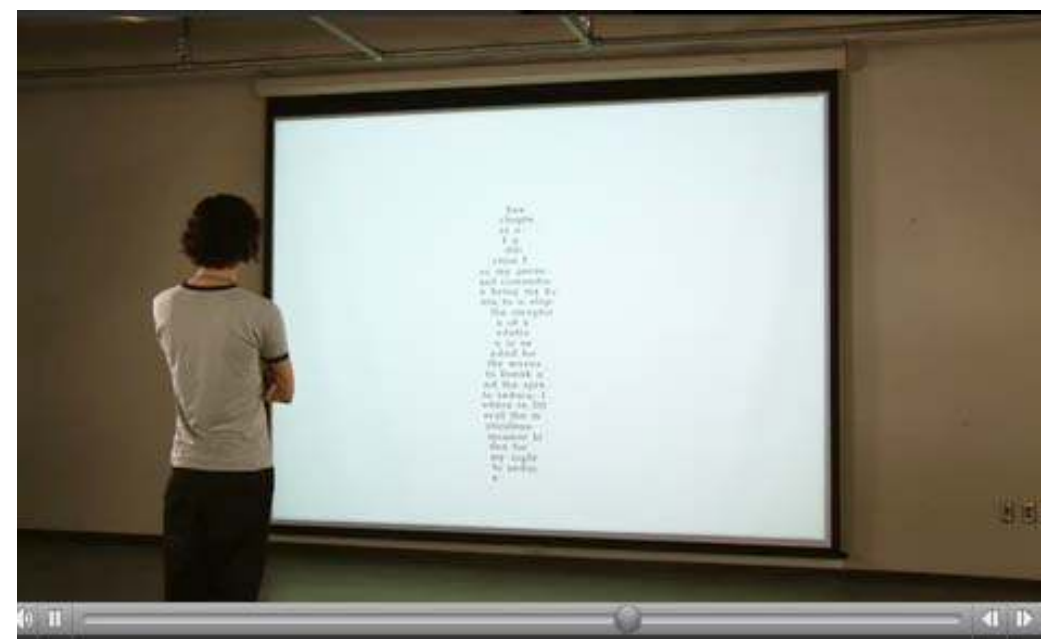

Fig.16 - Bruno Nadeau, Still Standing

To see and read this installation, the reader needs time, as well as for the other poems proposed. In a society of speed connection and in a place like internet, where the changing information is so fast, some digital poems propose a different relationship with time linked to the reading practice. As in the past, poetry needs time to be appreciated, but the "new" medium allows rising possibilities that touch not only the form of content, in Hjelmslev terms, but also the form (and the substance) of expression, creating a different relationship between the text body and the reader body.

\section{Collaborative Poetry and Text Generators: Who Is the Author?}

"Venuspoetry" is a rather simple project. The page opens with Botticelli's Venus; this painting hides 388 poems which are created by readers/authors.

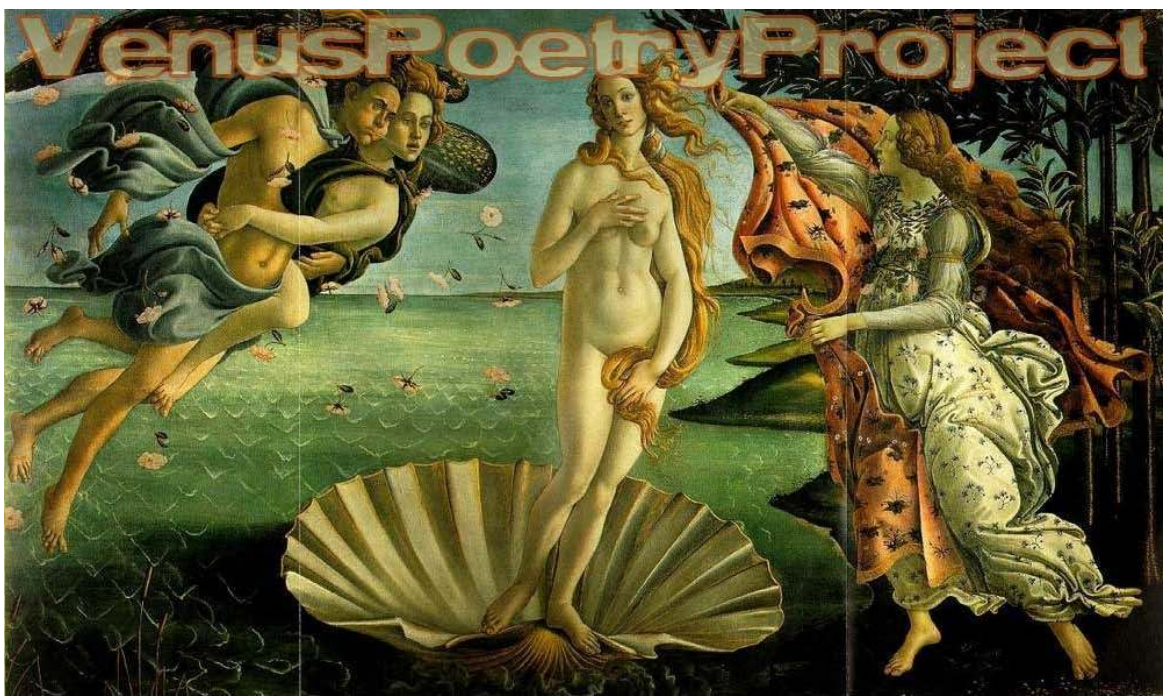


Fig. 16 - Venus Project

By clicking on any point of the image a poetic text will appear. So there is not a beginning, as in "traditional" poetry. Some texts are quite long, other made of just a verse line, and, finally, some are to be written. On the top of the screen a number indicates the poem. The web site is, evidently, under construction. The reader/author can decide either to write a new text or to modify texts which already exist. The action is very simple. He/she clicks on the text and thanks to the software he/she can directly type on the text. All the actions proceed in anonymity: there is no need to be registered or to create a nickname. It is very intuitive to use.

With collaborative poetry we have not only the "classical" problems of the interpretation and the author-function, but also what we may call the unpredictability of the work; every text, every creative practice will realize a single moment of the work. In these kinds of texts the involvement of the reader is increased to the point that his/her reading practice has to be converted into written practice so that the text perpetuates itself.

The reader is not simply "a participating subject" of a part of the text but an "involved subject". Unlike participation, collaboration does not recall socialization throughout the plurality of the readers-spectators, but it recalls the implication of a set of unique subjectivity. Furthermore as far as digital collaboration (as in opposition to participation) is involved, it does not mean to build a whole, nor to participate in a work in movement, but it deals with an "involved" subject to create the work, to create the movements of the work, the traces of the work, to re-write it so that it may keep on existing. In the collective texts, therefore, an object is built through a dialogue which begins with an author, but he/she only checks it partially.

Rob Malda's "Rob's amazing poem generator" is an interesting example of text generator. It uses the text contained in whichever web site in order to generate an accidental poetic text: it is sufficient to write an internet address. As the program is structured on English grammar, the best poetries are obtained by choosing English web sites. The result is a kind of words' collage. Even if more complex as far as its program, also this second generator risks to be more interesting for "making" than for what is "made", for the program than for the product. As for the reader-function, he/she decides what web site he/she would like to use. Somehow, the personal choice co-creates the text.

In this case, internet, instead of being only a publishing medium, is also a "productive medium". Quoting Looy and Baetens (2003: 21): "[...] the primary focus is not to produce literary, but rather to test the [...] capabilities of computer programs". Rob's amazing poem generator, by transforming intentional associations into non-intentional ones, is also related to the idea of "spontaneous emergence", permitted/caused by internet medium. 
The author of text generators defines the universe and makes the rules but over the text he/she has no control whatsoever, being so one can only agree with Balpe's words: "L'auteur n'écrit plus des textes mais des virtualités de textes " (Balpe, 1999: 7). In this sense a new relation is created within the sender-message-receiver triad (author-text-reader) in which the receiver actually acquires a primary role. Instead of talking about the author's individuality one should talk about the text's individuality (and sometimes about the reader that created that determined text.)

\section{Conclusion}

These examples show as e-poetry offers a very different variety of digital poems that require different practices to appoach the text, different practices of "witing" and "reading". The title of this paper contains a question: does e-poetry create a new genre of poetry? This paper has tried to demonstrate that different "genres" of e-poetry exist and that e-poetry produces a "new" relationship with the text, the reader and the author. The first examples insist on the materiality aspect of the language that becomes the message of the poems: playing with the materiality of e-poetry. Marie Bélisle's works focus on the relationship of image and form. Faith insists on the potentiality of e-writing as the dynamism: the dynamism is essential to understand the meaning of the text. Still Standing involves the "reader" in the creation act.

Collaborative texts puch the relationship between the author and the reader further the "reader" can decide to partecipate at the building of poetry, so he/she can choose to copartecipate at the dialogue which begins with an author, but which is only partially checked by the author. In this kind of texts the "reader" is invited to take part in the process of text creation: the reader in the role of co-author and poetry as an open structure. According to Carlo Infante (2002-2003), collaborative writing on the net exercises a new sensitivity: i.e. to pass from the expressive dimension to an associated search. And this is the important element: in hypertextual writings (and also in those hypermedial and/or generative), we always remain within domain of the expression, while with collaborative writing there is evidently an advancement, in that we are faced with a new social paradigm of the act of communication: to be author is no longer the most important thing; on the contrary, the writing is not any longer developed vertically but horizontally.

The collaborative work is not a finished product but a subjugated virtual reality because of the modifications of other authors/readers. We can actually define them as real wreaders. Wreader is a mixture of writer and reader, since it writes somehow its own text as he acts on it, as he develops the reading path in a way or another (Landow, 1997). With collaborative text the wreader becomes the conjunction of two practices: the reading and the 
writing ones. Thus the author of a collective work is actually a project-creator; he/she proposes a project which precisely proceeds thanks to the "rewriting" of other wreaders. Thus work is really open, but it is a transitory work. Indeed re-creative art it is an art of reality, of a reality in metamorphosis. An art combined at the present: hic nunc.

As for text generators, too the concept of author changes: the author is not an author anymore but a potential text author. It seems to materialize that kind of "positive dehumanization of the language" sought by Balpe (1990), in which it is the text/writing the priority element. This mechanical creation would seem to "de-valuate" the person and at the same time "re-valorise" (writing). As one easily understands as far as a generative and collaborative works is concerned, if the reader does not memorize his/her own choices through the text, that text will just fade without hope of it re-emerging. However, this fact seems unimportant as far as the subject's subjectivity is concerned, because in this way the subject co-traces his/her own text (making it unique).

Last but not least, all these texts give literature a ludic face. Even if in dissimilar forms, e-poetry propose a "primitive" literary experiment. In the "primitive" adjective one should not seek any negative connotations, but simply "which refers to a previous/earlier time", as the children who play with the language before learning how to speak, e-poetry plays with its form to create its content. Through digital poetry one starts again to have a visual, material and ludic relationship with the language.. Moreover, in collaborative and generative text the reader plays the role of the author, the author experiments programming or he/she shares his/her function. Through these texts it is possible to test a less "serious" relationship with literature. Obviously collaborative writing opens a problematic concerning authorship, but on the other hand this genre of writing allows a real horizontal link between author and reader. Nevertheless, examples of collaborative writing sites are not so numerous. It suggests that reader still needs author: writing poetry or fiction is a demanding purpose that could be amazing and fascinating but it is also difficult and ambitious. Finally, wreaders are not simple subject of the collaborative texts, but they should be considered as a "program" of the collective work, in fact if they stop working on the text, this text simply will die. 


\section{References}

AARSETH, Espen (1997) Cybertex: Perspective on Ergodic Literature, Baltimore, John Hopkins University Press.

AVETA, Michela, DE PASCALIS, Simona y SANZO, Francesco (2002-2003) «Intervista a Carlo Infante " in Bollettino 900, Newsletter della Letteratura Italiana del '900 Web page UNIBO http://www3.unibo.it/boll900/numeri/2002-i/W-bol/Infante/Infante.html/ (accessed December 3, 2008).

BALPE, Jean-Pierre (1999) «Pour une littérature informatique : un manifeste... » Web page Université Paris VIII: http://www.univ-reunion.fr/t99_mirroirs/multi_ct/littinfo/1_balpe.htm (accessed November 29, 2008).

BELISLE, Marie (1999) « Caractères » Web page Scriptura etcaetera in http://www.scripturae.com/CadresScript.htm/ (accessed November 7, 2008).

BELISLE, Marie (1999) «Figures » Web page Scriptura etcaetera in http://www.scripturae.com/CadresScript.htm/ (accessed November 7, 2008).

DeLEUZE, Gilles (1968) Différence et répétition, Paris: P.U.F..

ELUARD, Paul (1981) translated by Amy Levin in Levin A., Beilharz J., A Sampling of French Surrealist Poetry in English Translation, Dec. 1981 in http://www.alb-neckar-schwarzwald.de/ (accessed November 20, 2008).

Eco, Umberto (1962) Opera aperta, Milano, Bompiani.

ELO (2006) Electronic Literature Collection vol 1 in http://collection.eliterature.org/(accessed November 19, 2008).

FIX, Ulla (2001) « Zugänge zu Stil als semiotisch komplexer Einheit: Thesen, Erläuterungen und Beispiele », in Jakobs, Eva-Maria and Rothkegel, Annely, Tübingen: Niemeyer pp. 113-26.

GROS, Patrick (2007) L'indexation multimédia. Description et recherche automatiques, Paris: Hermes.

GREIMAS, Algirdas (1972) Essais de sémiotique poétique, (eds.) Paris: Larousse.

GROUP WRITING (2008) « Venuspoetry » Web page Venus Poetry Project inhttp://www.venuspoetry.com/ (accessed November 30, 2008).

HAYLES, Katherine (2008) Electronic Literature: New Horizons for the Literary. Flanner Hall, Indiana: University of Notre Dame Press.

HJEMSLEV, Louis (1943) Omkring Sprogteoriens Grundlæggelse (1943), tr. it. I fondamenti della teoria del linguaggio, Torino: Einaudi, 1975.

KENDALL, Robert (2002) «Faith» Web page Cauldron \& Net in http://www.studiocleo.com/cauldron/volume4/confluence/kendall/title_page.htm, or Electronic Literature Collection, Volume One, (2006), http://eliterature.org/2006/10/electronic-literature-/ (accessed November 12, 2008).

KRESS, Gunther and VAN LEEUWEN, Theo (2001) Multimodal Discourse Analysis - The Modes and Media of Contemporary Communication, London: Arnold.

KRISTEVA, Julia (1974) La révolution du language poétique, Paris: Seuil.

LANDOW, George (1997) Hypertext 2.0, The Convergence of Contemporary Critical Theory and Technology. Baltimore: The Johns Hopkins University Press.

LANDOW, George (2008) Hypertext 3.0: Critical Theory and New Media in an Era of Globalization. Baltimore: the Johns Hopkins University Press.

MALDA, Rob «Rob's amazing poem generator » Web page cmdrtaco.net in http://cmdrtaco.net/poemgen.cgi (accessed November 7, 2008).

McLUHAN, Marshall (1962) The Gutenberg Galaxy: The Making of Typographic Man, Toronto: University of Toronto Press. 
NADEAU, Bruno (2004-2005) Still Standing Web page Hermeneia in http://stillstanding.keenk.com/vids/ss_960x540.mov (accessed November 12, 2008).

SAEMmER, Alexandra (2007) Matières textuelles sur support numériques. St Etienne: Publications de l'Université de Saint Etienne.

VAn Looy, Jan and BAETENS, Jan eds. (2003) Close Reading New Media: Analyzing Electronic Literature Leuven: University Press. 